\title{
WHAT WILL TECHNOLOGY DO \\ TO FINANCIAL STRUCTURE?
}

\author{
Frederic S. Mishkin \\ Philip E. Strahan
}

Working Paper 6892

http://www.nber.org/papers/w6892

\section{NATIONAL BUREAU OF ECONOMIC RESEARCH 1050 Massachusetts Avenue \\ Cambridge, MA 02138 \\ January 1999}

Prepared for the conference, "The Effect of Technology in the Financial Sector," sponsored by the Brookings-Wharton Papers on Financial Services. Any views expressed in this paper are those of the authors only and not those of Columbia University, the National Bureau of Economic Research, the Federal Reserve Bank of New York, or the Federal Reserve System.

(C) 1999 by Frederic S. Mishkin and Philip E. Strahan. All rights reserved. Short sections of text, not to exceed two paragraphs, may be quoted without explicit permission provided that full credit, including ${ }^{\circledR}$ notice, is given to the source. 
What Will Technology Do to Financial Structure?

Frederic S. Mishkin and Philip E. Strahan

NBER Working Paper No. 6892

January 1999

JEL No. G2

\section{ABSTRACT}

This paper looks at how advances in information and telecommunications technologies have been changing the structure of the financial system by lowering transaction costs and reducing asymmetric information. Households and smaller businesses can now raise funds in securities markets as financial institutions have become better at unbundling risks, while financial products can be distributed more efficiently through electronic networks. These changes have reduced the role of traditional financial intermediaries, but have improved overall efficiency by lowering the costs of financial contracting. Despite these benefits, technological progress presents policymakers with some important challenges. First, as markets for financial products become larger and more contestable, defining geographic and product markets narrowly becomes more problematic. Second, financial consolidation and the trend towards new activities of financial intermediaries require the exploration of new methods to preserve the safety and soundness of the financial system. A combined system of vigilant supervision and constructive ambiguity to deal with failures of larger institutions should be capable of mitigating the potential for increased risktaking and help preserve the health of the financial system.

Frederic S. Mishkin Graduate School of Business

Columbia University

Uris Hall 619

New York, New York 10027

and NBER

fsm3@columbia.edu
Phillip Strahan

Research and Markets Analysis Group Federal Reserve Bank of NY

33 Liberty Street New York, NY 10045

Phillip.Strahan@ny.fbr.org 


\section{I. \\ Introduction}

In the last half of the twentieth century we have been experiencing an extraordinary technological revolution, especially in the computer and telecommunications fields. Twenty-five years ago, the latest computers not only took up whole rooms in computer centers, but were orders of magnitude slower and more expensive than today's PC that can easily be carried around in someone's briefcase. Transmitting information across long distance has become so cheap that our children think nothing of being in daily contact with their friends both across town and overseas. Clearly, the rapid pace of advances in information technology is having a profound effect on the economy. In this paper, we examine what impact this technological advance is likely to have on the structure of our financial system in the coming years.

In order to understand how technology affects financial structure, we first need to outline a framework which describes the fundamental forces that determine financial structure. Then we can go use this framework to see how technological progress is leading to changes in our financial structure. Although these changes are improving economic efficiency, they do present policymakers with important challenges. Thus we conclude the paper by discussing what new challenges policymakers are likely to face in the future and what steps might be taken in order to make sure that the changes in financial structure induced by technology end up benefitting the economy.

\section{II. Fundamental Forces Driving Financial Structure}

There are two primary forces that cause the financial system to take the form it does: 1) transaction costs and 2) asymmetric information. We look at each of these in turn and see how technology has profound effects on them.

\section{Transaction Costs}


Transaction costs, the time and money spent in carrying out financial transactions, can be a major impediment to the efficient functioning of the financial system. Think about having someone approach you with an excellent investment opportunity offering a high return but needing a ten thousand dollar loan. You have the cash and would like to lend them the money, but to protect your investment you have to draw up a loan contract that specifies how much the borrower will pay, when she will make the interest payments, and when she will repay the loan. Suppose that hiring a lawyer and drawing up the loan contract will cost one thousand dollars, then you might decide not to make the loan, even though you think that it is a good one, because the interest you can charge may not compensate for this transaction cost. The result is that a successful investment may not be undertaken, thus decreasing the efficiency of the economy.

Our financial system has developed to reduce these transaction costs so that productive lending can take place. For example, most lending is done by financial intermediaries, institutions such as banks, insurance companies, mutual funds, pension funds and finance companies, who acquire funds from individuals and firms with excess savings and then lend them out to others. Financial intermediaries can take advantage of economies of scale, the reduction in transaction costs per dollar of transactions as the size (scale) of transactions increases. For example, a bank knows how to find a good lawyer to produce an airtight loan contract, and this contract can be used over and over again in its loan transactions, thus lowering the legal cost per transaction. Thus a bank has no trouble making the loan that you personally might have to pass up because you faced a burdensome transaction cost. Similarly, it might be too expensive for an individual to purchase ten shares of stock because the transactions cost per share are high when the number of shares bought is small. On the other hand if the purchases of many individuals can be bundled together, as occurs when a mutual fund buys stock on behalf of its investors, then the cost of buying that stock will be substantially reduced and more funds will be directed to the equity markets.

The advances in computer and telecommunications technology clearly has a major impact on transactions costs. The advent of computers and cheap data transmission has led to a sharp decline in transactions costs. This has made and is continuing to make the financial system more efficient by increasing the number of transactions that are feasible and also by enabling financial 
institutions to provide new products and services that would have been too costly in the past. We will see that the rapid fall in transactions costs stemming from technological advances is a key factor that is transforming our financial system.

\section{Asymmetric Information}

The presence of transaction costs is just one impediment to the efficient functioning of the financial system. Just as important is the presence of asymmetric information, the fact that one party to a financial transaction often does not know enough about the other party to make accurate decisions. For example, a borrower usually has better information about the potential returns and risk associated with the investment projects for which the funds are earmarked than the lender does. Lack of information creates two types of problems in the financial system: adverse selection and moral hazard.

Adverse selection is an asymmetric information problem that occurs before the transaction occurs when potential bad credit risks are the ones who most actively seek out a loan. Thus, the parties who are the most likely to produce an undesirable (adverse) outcome are most likely to be selected. For example, those who want to take on big risks are likely to be the most eager to take out a loan because they know that they are unlikely to pay it back. Since adverse selection makes it more likely that loans might be made to bad credit risks, lenders may decide not to make any loans even though there are good credit risks in the marketplace. This outcome is a feature of the classic "lemons problem" analysis first described by Akerlof (1970). Clearly, minimizing the adverse selection problem requires that lenders must screen out good from bad credit risks.

Moral hazard occurs after the transaction takes place. Lenders are subjected to the hazard that the borrower will engage in activities that are undesirable from the lender's point of view: i.e., activities that make it less likely that the loan will be paid back. Moral hazard occurs because a borrower has incentives to invest in projects with high risk in which the borrower does well if the project succeeds but the lender bears most of the loss if the project fails. Also the borrower has incentives to misallocate funds for her own personal use, to shirk and just not work very hard, or to undertake investment in unprofitable projects that increase her power or stature. The conflict 
of interest between the borrower and lender stemming from moral hazard implies that many lenders will decide that they would rather not make loans, so that lending and investment will be at suboptimal levels. ${ }^{1} \quad$ In order to minimize the moral hazard problem, lenders must impose restrictions (restrictive covenants) on borrowers so that borrowers do not engage in behavior that makes it less likely that they can pay back the loan; then lenders must monitor the borrowers' activities and enforce the restrictive covenants if the borrower violates them.

Another concept that is very important in understanding the impediments to a wellfunctioning financial system is the so-called free-rider problem. The free-rider problem occurs because people who do not spend resources on collecting information can still take advantage of (free ride off) the information that other people have collected. The free-rider problem is particularly important in securities markets. If some investors acquire information that tells them which securities are undervalued and then buy these securities, other investors who have not paid for this information may be able to buy right along with the well-informed investors. If enough free-riding investors can do this, the increased demand for the undervalued securities will cause their low price to be bid up to reflect the securities' full net present value given this information. As a result of all these free riders, investors who have acquired information will no longer be able to earn the entire increase in the value of the security arising from this additional information. The weakened ability of private firms to profit from producing information will mean that less information is produced in securities markets, so that the adverse selection problem, in which overvalued securities are the those most often offered for sale, is more likely to be an impediment to a well-functioning securities market.

More importantly, the free-rider problem makes it less likely that securities markets will act to reduce incentives to commit moral hazard. As we have seen, monitoring and enforcement of restrictive covenants are necessary to reduce moral hazard incentives for borrowers to take on risk at the lenders expense. However, because monitoring and enforcement of restrictive covenants are costly, the free-rider problem discourages this kind of activity in securities markets.

\footnotetext{
${ }^{1}$ Asymmetric information is clearly not the only source of the moral hazard problem. Moral hazard can also occur because high enforcement costs might make it too costly for the lender to prevent moral hazard even when the lender is fully informed about the borrower's activities.
} 
Once some investors know that other securities holders are monitoring and enforcing the restrictive covenants, they can free ride on the other securities holders' monitoring and enforcement. When these other securities holders realize that they can do the same thing, they also may stop their monitoring and enforcement activities, with the result that not enough resources are devoted to monitoring and enforcement. The outcome is that moral hazard is likely to be a severe problem for marketable securities.

We now see why the adverse selection, moral hazard and the free-rider problems hinder the efficient functioning of financial markets. Indeed, financial intermediaries play a key role in reducing these adverse selection and moral hazard problems because they avoid the free-rider problem by originating private loans that can not be bought by outside investors. Thus, financial intermediaries are able to reap the full benefit of the information and monitoring services they provide.

Given the fact that computers and telecommunications technology is referred to jointly as information technology, it should be no surprise that advances in this technology are having profound effects on the degree of asymmetric information in financial markets and thus on financial structure. With the improvement in information technology, it becomes easier for investors to screen out good from bad credit risks or to monitor corporations, thus reducing the adverse selection and moral hazard problems. The result is that the barriers to issuing marketable securities decline, thus encouraging their issue. The resulting increase in the ability to raise funds through marketable securities has been having profound effects on our financial structure, as we will see below. 


\section{III. The Impact of Technology on Financial Structure}

Innovations in computer and telecommunications technologies that reduced both transactions costs and asymmetric information problems have led to three key changes in financial markets. First, debt markets have become larger and less dominated by financial institutions, with an increasing share of debt instruments becoming tradable. Second, derivatives markets have grown, allowing firms to trade market risks cheaply. Third, payments systems are moving towards an electronic system that is reducing the need for households to invest their wealth in the form of bank deposits. As a consequence, both the role of financial intermediaries and the structure of the financial system have changed profoundly.

\section{Changes in Debt Markets}

Improvements in information technologies have reduced asymmetric information in financial markets and mitigated adverse selection and moral hazard problems. Assets that were previously held on the balance sheets of financial institutions can now trade, in part, because it is easier for third-parties to value them. Transactions costs have also fallen as financial institutions have learned how to unbundle and repackage risks, allowing them to create non-information intensive securities from opaque ones that third-parties can value and trade, while maintaining a first-loss position that concentrates most of the risk. The use of automated underwriting and credit scoring for residential mortgages, credit card loans, and small business loans have also reduced the fixed costs of making these loans. This decline in the transactions cost of writing these contracts has both increased the supply of these kinds of credits and enhanced their liquidity. As a result, debt markets have grown -- the ratio of total private, non-financial debt to GDP has nearly doubled since the early 1960s (Figure 1). ${ }^{2}$ Credit to large businesses, small businesses and

\footnotetext{
${ }^{2}$ In contrast, the ratio of the market value of equity to GDP in the 1990s was at levels seen during the 1960s.
} 
households have all changed as a result.

\section{Credit extended to large businesses}

Figure 2 summarizes changes in the source of credit to non-financial corporate business since 1970. Commercial paper and bonds have grown in importance, while loans have declined. What appear to be relatively gradual changes, however, mask developments that have made both loans, as well as privately-placed bonds, more liquid and marketable over time.

The commercial paper market emerged in the 1970s. The market has grown slowly but steadily over the past 20 years, accounting for about five percent of total non-financial corporate borrowing in 1998. Many large businesses now use commercial paper to finance working capital instead of bank lines of credit. This market exists both because of better general information about large businesses, and because of declines in transactions costs -- banks now know how to provide off balance sheet credit enhancements so that most of the credit risk associated with the commercial paper often remains with them, while most of the funding comes from third parties and trades in markets.

While the share of loans from banks and other intermediaries fell only slightly, the loans that remain on the balance sheets of intermediaries are becoming increasingly liquid and tradable. In the late 1980s and early 1990s, banks began to securitize portions of their commercial and industrial (C\&I) loan portfolios and their commercial mortgage portfolios (Figure 3). About three percent of C\&I loans are now securitized, and about 12 percent of commercial mortgages are securitized. Loan syndications and participations to large and medium-sized borrowers have also grown rapidly in recent years. The volume of syndicated loans rose from \$137 billion in 1987 to $\$ 888$ billion in 1996 (Figure 4). While loan syndications do not trade in liquid secondary markets, a dealer market has existed since the late 1980s (Bhasin and Carey, 1998). By 1996 annual volume between 22 dealers in this market topped $\$ 41$ billion. $^{3}$

Corporate bonds have also become more liquid over time. The share of total corporate

\footnotetext{
${ }^{3}$ See Loan Pricing Corporation, Gold Sheets, 1997.
} 
bonds issued in public bond markets has risen from 55 percent during the 1960s, to 65 percent during the 1970s, to 68 percent during the 1980s. ${ }^{4}$ As with bank lending, however, this relatively gradually increase masks a change in the nature of private bonds as an increasing share of these are now traded in the so-called Rule 144A market. Bonds issued under Rule 144A require greater disclosure standards than non-Rule 144A private placements and are more easily traded among certain classes of institutional investors. Carey, Prowse, Rea and Udell (1993) provide a detailed description of this market and argue that its crucial feature seems to be that information production and monitoring is much easier than in the traditional market for private placements. As a result, 144A issues are more like public bonds than private bonds. This market has grown dramatically since its inception in $1990 .^{5}$

\section{Credit extended to small businesses}

Since the early 1990s, banks and finance companies have begun to use credit scoring to underwrite loans to small businesses. Credit scoring models use widely available information about borrower quality, such as the credit history of the proprietor, to estimate the likelihood that a particular small business loan will default; loan applications with a sufficiently low default likelihood (high "score") are granted. Such models are very common for credit card lending and work in very similar ways when applied to small business loans. Of course, in practice banks may incorporate judgement based on a loan officer's experience to override the advice of a credit scoring model. Survey evidence suggests that large banks have been the first to use credit scoring for their small business loans, and that these models are generally used only for very small, small business loans such as those under $\$ 100,000$ (Mester 1997).

Securitization of small business lending has begun, albeit slowly, because technologies such as credit scoring have made these loans more standardized (i.e. lowered the transactions costs of securitizing them) and more transparent (i.e. lowered the asymmetric information cost of

\footnotetext{
${ }^{4}$ These figures are based on authors' calculations from Carey et al (1993), Table D.1.

${ }^{5}$ Unfortunately, it is difficult to get accurate figures on the breakdown between the stock of privately-placed and public bonds, as well as the breakdown between 144A and non-144A privately-placed bonds.
} 
securitizing them). Some finance companies such at the Money Store have securitized their Small Business Administration (SBA) loans. Significantly, both the guaranteed and non-guaranteed portions have been securitized. The recently passed Small Business Loan Securitization and Secondary Market Enhancement Act also loosened accounting and regulatory treatments of loan sales for banks. As banks and finance companies increase their use credit scoring for business lending, we may begin to see significant growth in securitization of these loans down the road.

\section{Credit extended to households}

Beginning in the 1970s, the Government-Sponsored Enterprises (e.g. Fannies Mae and Freddie Mac) began issuing mortgage-backed securities. In the early 1980s, private-sector investment banks also began issuing mortgage-backed securities and began repackaging the risks associated with these products by creating various tranches based on prepayment behavior. This innovation allowed relatively less sophisticated investors to hold the easily valued portion of mortgages, while concentrating the more difficult to value prepayment risk with sophisticated

investors. In 1980, about 10 percent of mortgages outstanding were securitized, and by 1998 the share of securitized mortgages exceeded 50 percent (Figure 5).

During the 1980s, securitization of other kinds of debt instruments began to grow rapidly. As with small business lending, credit scoring technologies have facilitated securitization of consumer loans that in the past had to remain on bank (and other intermediary) balance sheets. Starting from near zero in 1988, about 45 percent of credit card loans are now securitized. While banks are not securitizing their other consumer loans to a high degree, finance companies have done so in recent years. Overall, about 12 percent of all auto loans were securitized in 1998, while about nine percent of other consumer loans were securitized (Figure 6).

\section{The Rise of Derivatives Markets}

During the last two decades we have witnessed the introduction of markets that facilitate trading of market risks, such as the risks associated with changes in foreign exchange rates and 
interest rates. These so-called derivatives markets began to emerge in the 1970s when the Chicago Board Option Exchange introduced trading in options. During the 1980s, over-thecounter derivatives markets began to grow rapidly, with financial institutions, especially banks, acting as market makers. Because the growth of these markets has been discussed extensively elsewhere [see Edwards and Mishkin, 1995, and Allen and Santomero, 1997, for example], we discuss them only briefly here.

These markets probably emerged for both supply-side and demand-side reasons. The macroeconomic turbulence of the 1970s and the associated instability in both exchange rates and interest rates probably raised the demand by firms for better management of these systematic risks. On the supply side, better financial theory has allowed financial institutions to act as dealers in these markets at low cost. Options markets took off after Black, Scholes and Merton showed traders how to create options synthetically by taking long and short positions in the underlying securities. This fundamental insight led to a new field in finance -- financial engineering -- in which highly-trained mathematicians provide traders with an algorithm to price and manage the risks associated with any derivative security that depends only on the movements of underlying exchange rates, interest rates, etc. Derivatives markets have become very large in recent years. Notional amounts for all OTC derivatives contracts as of March 1995 exceeded \$40 trillion, with a market value of about $\$ 1.7$ trillion (Allen and Santomero 1997).

\section{Changes in Payments Technologies}

Declines in transactions costs have had an important effect on the liabilities of financial institution, particularly banks. In the past, the bulk of retail payments in the U.S. were made using paper checks. This system gave commercial banks a natural source of funding, the demand deposit, which was supplied relatively inelastically. Recent evidence suggests that this pool of reliable funds may have been critical to the special role of banks in providing loans to businesses. One of the advantages for borrowers establishing a long-term banking relationship is the bank's ability to provide insurance against shocks to the borrower's credit that could, in the absence of such insurance, lead to costly financial distress and inefficient liquidation of assets. Such 
insurance is only feasible, however, if the bank has access to a stable source of funds (Berlin and Mester, 1997).

In recent years, the use of electronic payments technologies have grown explosively. Automated Teller Machines (ATMs) are continuing to expand rapidly. Although this technology goes back to the middle of the 1970s, the number of ATMs more than doubled between 1988 and 1998, and the number of transactions almost tripled over that period. In addition, the use of credit cards and debit cards to make payments at the point of sale has grown very rapidly during the 1990s. Credit card volume doubled between 1993 and 1997, and debit card volume increased by a factor of more than five over the same period. ${ }^{6}$ While the U.S. retail payments system does continue to rely very heavily on paper checks, and the volume of checks continues to increase, the growth rate in electronic payments far surpasses the growth in check volume.

These technologies, by increasing the speed and efficiency of payments, reduce the need to hold demand deposits as well as other bank deposits. A consumer today, for instance, can make all but the smallest payments with a credit card, and then make a single payment by check at the end of the month. By consolidating payments in this way, the average balance in the checking account can be much lower than in the past. Households can now hold the vast bulk of their wealth in mutual funds and pension funds and make payments electronically. As a result, the share of household wealth held in bank deposits fell from 15.3 percent in 1983 to 7.3 percent in 1995 (Wolf 1998).

Banks are also developing electronic channels -- phone centers, ATMs, and home banking -- to market and deliver their services to household customers outside of branch offices in order to cut costs and to increase convenience for the customer. The immediate goal is to take routine transactions and service requests out of branches so that the branch network can be trimmed. Phone centers, ATMs and PC banking create opportunities for some cost savings within the framework of the current branch structure (Radecki, Wenninger and Orlow, 1997).

\section{Consequences of New Technologies}

\footnotetext{
${ }^{6}$ See The EFT Network Data Book, Bank Network News, 16(9), 1997.
} 
As a result of these changes, the role of financial institutions is changing. In the past, financial institutions issued claims to back their holdings of primarily private, informationally intensive illiquid assets. Today, they mainly allow investors to hold a well-diversified portfolio of marketable securities at low cost. The increasing importance of mutual funds and pension funds over the past two decades is a reflection of this changing role. Since 1980 the combined market share of pensions and mutual funds more than doubled, rising from 20.9 percent to 49.3 percent today. By contrast, commercial banks' market share fell by half, from 36.6 percent to 24.2 percent. Depository institutions' overall share fell from 57.8 percent to 30.7 percent (Table 1). Moreover, as debt markets have become more liquid, a much greater share of traditional intermediaries' (e.g. banks and insurance companies) assets are marketable today than in the past; banks today look more like mutual funds, at least on the asset side of the balance sheet, than ever before. The traditional banking business of issuing short-dated deposits to acquire longer-term loans, commonly referred to as "borrowing short and lending long" is also declining in part because the greater use of electronic payments has reduced the supply of deposits.

As pointed out in Edwards and Mishkin (1995), given the decline in their traditional business, there are two routes for financial institutions to take in order to keep their profitability high. First they can attempt to maintain their traditional lending activity by expanding into new, riskier, areas of lending. This is exactly what commercial banks did when they placed a greater percentage of their total assets in real estate loans, as occurred in the 1980s in almost all countries throughout the world. Unfortunately, the result has been large loan losses, and this is particularly problematic currently in Japan, where estimates of the amount of nonperforming loans loan in the banking system now exceed $\$ 500$ billion.

A second route for financial institutions to maintain profit levels is to pursue new, offbalance sheet, activities. For example, financial institutions now facilitate the unbundling and trading of risks, both by acting as dealers in derivatives markets, and by through securitization of mortgages and consumer and business loans. One result has been a large increase in the share of income at banks (noninterest income plus net interest income) that comes from off-balance sheet, noninterest-income activities, which for example rose from 20 percent to 38 percent between 1980 and 1997 (Figure 7). 
Technological innovations also seem to be increasing economies of scale in financial services. Research based on data from the 1980s found very limited economies of scale in banking; the location of the minimum efficient scale was usually found to be somewhere between about \$100 million and \$300 million in assets, and some studies found small diseconomies of scale at the high end of the bank size distribution (e.g., Berger, Hunter and Timme, 1995). Recent efforts to measure scale economies using data on U.S. banks from the 1990s, however, have found economies of scale up to $\$ 10$ to $\$ 25$ billion in assets (Berger and Mester, 1997). Technologies such as credit scoring models, which rely on statistical analysis of default risks, require large databases on loan default histories, giving large lenders a significant advantage over their smaller competitors. For instance, BankAmerica used about 30,000 small business loans to develop a credit scoring model (Oppenheim 1996, Mester 1997). In addition, electronic payments technologies require large fixed investments and often require networks that exhibit increasing returns. Although there are no econometric studies that estimate the effect of these new technologies directly, recent evidence suggests that electronic payments processing at the Federal Reserve Banks have exhibited significant scale economies (Hancock, Humphrey and Wilcox, forthcoming).

As a result of these increased economies of scale, we have witnessed rapid consolidation during the 1990s. To date, this consolidation has had the most dramatic impact in banking because of deregulation of restrictions on geographic and product markets. Deregulation itself, however, occurred in large part because technological progress changed the political-economy equilibrium that had remained stable since the Great Depression. Restrictions on bank branching, for example, occurred because small bank interests defeated those of large banks during the 1920s and 1930s (Economides, Hubbard and Palia, 1995). Kroszner and Strahan (1998) argue that recent technological changes that diminished asymmetric information problems reduced the value of specialized local knowledge that long-established local bankers had about the risks of borrowers in the community. Such changes increased the feasibility and potential profitability for large banks to enter what had traditionally been the core of small bank activities. Large banks therefore had an incentive to increase their lobbying pressure to attain the freedom to expand into these markets. Small firms, the main borrowers from the small banks, also became more likely to favor the entry 
of large banks into local markets as large banks have become better able to lend efficiently to them. In addition, the increasing availability of substitutes for deposits reduced the value of geographical restrictions to their traditional beneficiaries, thereby reducing their incentive to fight strenuously to maintain them. These changes therefore tipped the balance in favor of large bank interests. As evidence, Kroszner and Strahan (1998) show that states that deregulated their restrictions on branching early tended to be those with fewer small banks, with more financially weak small banks, and with more small potential borrowers.

Much of the consolidation in the 1990s has occurred between very large banking organizations (top-tier bank holding companies and stand-alone banks). There were an average of only seven mergers per year of banking organizations with assets over $\$ 1$ billion during the 1980s, compared with 17 large-bank mergers per year during the 1990s (Rhoades 1996). As a result, the share of assets held by the very largest banking organizations -- those with assets over $\$ 100$ billion -- increased from 8.5 percent in 1990 to 33.2 percent in 1998 (Table 2). We have also seen some consolidation between banks and small securities firms in recent years, and the merger of one of the largest commercial banks (Citicorp) with one of the largest insurance and securities underwriters (Travelers) was proposed in the spring of 1998 (Berger, Demsetz and Strahan, forthcoming).

Changes in the delivery of retail financial services may also increase the size and competitiveness of geographical markets. As noted, banks are moving toward electronic delivery modes that do not rely on a branch network. Indeed, the number of banking offices has fallen somewhat over the last decade, and many banks are replacing full service branches with supermarket branches that offer little more than a cluster of ATMs (Radecki, Wenninger and Orlow, 1997). Some banks are also instituting fee structures that encourage customers to avoid using branches. There would seem to be no advantage for a local bank if customers interact with their bank through ATMs, telephones and PCS.

Credit scoring may also lead to bigger and more competitive markets for small business lending. Traditionally, small businesses would use a local bank for checking, lines of credit and cash management services. But in 1996, Wells Fargo began using credit scoring to approve small business loans. As a result of their national solicitation campaign, their portfolio of small business 
loans rose by about one-third between June 1995 and June 1996. In time, banking products for small businesses may be offered routinely in national markets. In addition, credit scoring seems to reduce the fixed costs associated with screening potential borrowers. As a consequence, banks are becoming more willing to make very small loans to small businesses. Levonian (1997) finds that these credit scoring technologies have been applied mainly to very small business loans, those under $\$ 100,000$, and have facilitated rapid expansion of these loans by very large banking companies in the 12th Federal Reserve District.

\section{IV. Policy Issues}

The changing role of traditional intermediaries and financial consolidation, both driven by the technological change in financial services, raise two important policy issues. First, traditional antitrust concerns about market power need to be re-considered in this new environment. Second, the decline of their traditional businesses and the increasing size and complexity of financial institutions raises potential problems for the operation of the safety net under the financial system.

\section{Antitrust}

Regulators currently prevent mergers between banks operating in overlapping local markets if excessive increases in concentration or market share would result. The analysis of product markets since the mid-1960s has been based on the idea that banks provide a "cluster" of services to their customers (e.g. deposits, loans and transactions services) that can be viewed as a single product. Hence, measures of concentration are based on total deposits. Geographic markets are defined locally, such as a Metropolitan Statistical Area (MSA) or a non-MSA county. This approach has been justified by research results, detailed below, of the pricing of bank retail products during the 1980s, as well as survey evidence. Technological progress has had two effects with implications for this policy, however. First, new technologies have reduced barriers to entry and increased the size of markets. Market are becoming more open, and this change is clearly for 
the better. More competition forces firms to minimize costs and innovate, but it poses a clear challenge to antitrust policymakers who must define the relevant geographic and product market to do their job. Second, more open markets offer opportunities for firms to expand market share, either because they have lower costs than their competitors or because acquisition of market share is an end in itself. ${ }^{7}$ Recent research suggests that many new technologies in financial services exhibit increasing returns, and we have clearly seen rapid consolidation in banking in recent years. Increased concentration and possible expansion of market power may be a source of concern.

\section{Market Openness}

Technological progress has made markets for financial services products more competitive and contestable. Financial products and services have become more standardized, and search costs have fallen as these products become more likely to be distributed by phone, mail and PCS via the internet rather than through traditional brick and mortar. Technologies like ATMs have directly expanded the size of deposit markets in banking; suburban banks now compete more directly with urban banks than in the past. Credit scoring of small business loans seem to be expanding this market from a local one to, perhaps, a national one. In addition, financial products that used to be provided by only one kind of financial institution are now provided by many. Commercial banks are now in the business of making residential mortgages, and thrifts do significant amounts of commercial lending. Many states permit banks to sell insurance, and national banks can now offer these products to some extent. As noted above, technological innovation has also indirectly caused markets to become more open and competitive by spurring deregulation.

Research suggests that declines in barriers to entry and expansion of the size and openness of markets for financial services has had a series of beneficial effects. Jayaratne and Strahan (1998) exploited differences in the timing of state-level deregulation of restrictions on bank

\footnotetext{
${ }^{7}$ There is some evidence that entrenched managers may look to expand beyond that level that maximized shareholder value through M\&A activity. For a summary, see Berger, Demsetz and Strahan (forthcoming).
} 
expansion through branching to show that the efficiency of the banking sector improved after deregulation -- both non-interest costs and loan losses fell significantly. They found that costs fell because the more efficient banks gained market share at the expense of the less efficient banks. For each state that deregulated, the authors first ranked banks from highest to lowest according to their profitability the year before deregulation. Next, they divided the banking sector into two halves: the more profitable half, and the less profitable half. The key result is that the more profitable half gained 8.5 percent of the market over the six years following deregulation. A similar exercise done in states that did not deregulate found no tendency for better run banks to gain market share over time.

More open markets may also lead to cost declines at individual firms both because of more vigorous competition and because of more active corporate control markets. Cost declines at individual firms would tend to reinforce the effects of the expansion of the better run firms. As evidence, Schranz (1993) found that deregulation of interstate banking restrictions in the U.S. led to increased bank profits because a more active takeover market forced managers to maximize firm value. Hubbard and Palia (1995) found that after interstate banking deregulation, turnover of senior managers became more likely. They also found that the compensation of bank CEOs became more sensitive to performance, giving them more incentive to maximize profits.

Of course, cost declines need not be passed along to consumers if there is market power. Moreover, opening markets often leads to increases in concentration. The rapid expansion of better run, more efficient banks can lead to increased concentration due to the scarcity of managerial talent. In fact, state-level measures of concentration did increase after branching deregulation. But if enhanced market power were a problem, we would see higher prices at the local level following deregulation. In contrast, bank loan interest rates fell, on average, while deposit rates remained unchanged (Jayaratne and Strahan 1998). If anything, geographic restrictions probably increased market power by limiting entry. Evanoff and Fortier (1988) found that profits increased as local banking markets became more concentrated (measured in terms of the deposit share of the top three banks in a market), but this affected only those states that restricted branching. Potential entry into local banking markets appears to discipline incumbents and prevent the exercise of market power. In addition, Keeley (1990) found declines in bank 
franchise value following deregulation of restrictions on bank's ability to expand, and interprets this as evidence that access to rents declined following deregulation.

\section{Increased Concentration}

Research of banking markets using data from the 1980s suggested that prices and profits were higher in more concentrated local markets. (Local markets in the U.S. are usually defined for research and policy purposes as Metropolitan Statistical Areas (MSAs) or non-MSA counties.) Studies generally found that banks in more concentrated markets charged higher rates on small business loans and paid lower rates on retail deposits (e.g., Berger and Hannan 1989). In addition, bank deposit rates appeared to be less sensitive to changes in market interest rates in more concentrated markets, and this "stickiness" was greater with respect to rate increases than decreases (Hannan and Berger 1991, Neumark and Sharpe 1992, Jackson 1997). These results are consistent with market power exercised at the local level increasing in the concentration of these markets.

Recent evidence using data from the early 1990s, however, suggests that the effects of local market concentration may be declining. Bank fees on retail deposit and payments services in the 1990s show very little relationship with measures of local market concentration (Hannan 1998). ${ }^{8}$ The relationship between local market concentration and both profits and deposit rates also seems much weaker in the 1990s than the 1980s (Hannan 1997, Moore and Siems 1998, Radecki 1998), although the relationship between local market concentration and small business loan pricing still appears to be strong and may be even stronger (Cyrnak and Hannan 1998). ${ }^{9}$ The recent data also suggest that banks often set uniform rates for deposits and loans over a state or region of a state that depend on competitive conditions over these larger areas, rather than at the local market level (Radecki 1998).

\footnotetext{
${ }^{8}$ An interesting finding in Hannan (1998) is that multistate bank holding companies tend to charge higher fees to retail customers, consistent with a focus on other lines of business.

${ }^{9}$ In part, the changes in the measured effects of concentration on deposit rates may reflect changes in the survey instruments used to collect the rate data.
} 
Radecki (1998) also found that measures of concentration in banking at the state level appear to be related to prices. Based on data from 1996, banks located in states with a higher three-firm concentration ratio pay lower interest on NOW accounts and savings accounts; there is also some evidence that they also pay lower rates on 6-month CDS. As noted above, local concentration has changed very little in the U.S. (which now seems to matter much less for pricing), but state-level concentration has increased sharply (which now seems to matter more for pricing). The share of total bank assets held by the largest eight banking organizations rose from 22 percent in 1988 to 36 percent in 1997 . With almost complete deregulation of banks' ability to expand nationally following passage in 1994 of the Interstate Banking and Branching Efficiency Act of 1994 (IBBEA), we can probably expect continued increases in concentration at the national level. One wonders whether national measures of concentration will become the important indicator of market power in the future.

\section{Should the approach to antitrust change?}

With markets becoming larger and more contestable, it seems clear that policy makers will eventually move away from the approach of focusing on local concentration. A focus on larger markets in the future makes sense because the pricing of some banking products appears to be related to concentration measured across larger markets. ${ }^{10}$ The good news for policymakers is that greater market openness will enhance competition and lower costs. However, concentration will probably continue to increase. The bad news is that with rapidly changing geographical and product markets, we do not know how to construct accurate market definitions with complete confidence in a timely way. Policymakers will need new definitions of market boundaries because use of old definitions can stifle the best firms' opportunities to grow and prosper, thereby seriously decreasing the efficiency of the financial system.

10 In fact, the recently passed IBBEA does limit concentration by capping the total amount of insured deposits that any banking organization may own at 10 percent. The cap may have immediate consequences. If the proposed merger with BankAmerica goes through, NationsBank will have more than 8 percent of insured deposits in the U.S., so its ability to acquire another large banking company may be hampered by the deposit cap. 


\section{Safety and Soundness}

Financial consolidation and a changing role for traditional financial intermediaries, both of which have resulted from rapid technological change, also have implications for what policies are needed to foster the safety and soundness of the financial system. As we have seen, the increased competition driven by technology has made the traditional borrowing and lending business of financial intermediaries less profitable and this creates incentives for them to take on increased risk, either through riskier strategies in their traditional lending business or by seeking out new, risky activities. Indeed, one factor which has helped produce the worldwide banking crises of recent years is increased risk-taking on the part of banks who have seen the value of their traditional business franchise decline.

One response to the potential for increased risk-taking by financial intermediaries is to restrict them from engaging in the new activities that technology now opens up to them. This strategy is highly problematic because it would prohibit activities that enhance economic efficiency. Furthermore, prohibiting financial institutions like banks from pursuing these activities would surely weaken their competitive position, which could in itself lead to lower profitability and failures that result in financial instability.

Vigilant prudential supervision of financial institutions is a more appropriate strategy to deal with the potential for increased risk-taking. This strategy involves capital standards and prompt corrective action provisions like those in the Federal Deposit Insurance Corporation Act (FDICIA) of 1991, the provision of adequate resources and statutory authority to bank supervisors so they have the ability to prevent excessive risk-taking and close down insolvent institutions quickly, adequate independence and insulation of the supervisory authorities so they can resist political pressure to engage in regulatory forbearance, and transparency and accountability of supervisors so they have the appropriate incentives to do their jobs properly. Although these elements are the usual ones that are raised as essential elements of any supervisory scheme (e.g., Mishkin 1998), there are two other elements that deserve special attention because of the challenges that technological progress has presented.

Technological change has made financial intermediaries activities more complex in a way 
that makes less effective the traditional approach to supervision, which emphasizes capital adequacy standards. First, new technologies such as securitization allow banks to sell the safer components of their loan portfolios and leave the riskier, more opaque components on the balance sheet. As a consequence, risk-based capital standards that apply weights to various classes of assets based on the average riskiness of these asset classes are becoming increasingly divorced from the actual risks that remain with the banks. Second, technological change has produced new markets and instruments which make it easy for banks and their employees to make huge bets quickly. In this new financial environment, a bank that is quite healthy at a particular point in time can be driven into insolvency extremely rapidly from trading losses, as has been forcefully demonstrated by the failure of Barings in 1995 which, although initially well capitalized, was brought down by a rogue trader in a matter of months.

This change in the financial environment requires a major shift in thinking about the supervisory process. As a result, supervisors both in the United States and elsewhere are now placing far greater emphasis on evaluating the soundness of bank's management processes with regard to controlling risk. New methods for supervisors to assess the risk management procedures of the institutions they supervise and to make sure that proper internal controls are in place are being developed, and continuing attention to and research on risk management needs to be a high priority in the future.

Financial consolidation also presents an important challenge to policymakers because there will be more large financial institutions, and the failure of a large financial institution makes it more likely that a major, systemic disruption to the financial system will occur. Indeed, the fear of systemic risk has led bank supervisors in most countries to either explicitly or implicitly have a toobig-to-fail policy in which all depositors at a big bank, both insured and uninsured are fully protected if the bank fails. The problem with a too-big-to-fail policy is that it reduces market discipline on big banks and thus increases their moral hazard incentives to take on excessive risk. It does this because depositors and uninsured creditors of the large bank know that they will be paid off in full when the bank fails and so have little incentive to monitor this institution and impose market discipline on the bank by withdrawing funds if the bank is taking on too much risk.

How can bank supervisors deal with the quandary of not wanting to allow a large bank 
failure to destabilize the financial system, while keeping the moral hazard problem created by toobig-to-fail under control? One proposal outlined in Mishkin (forthcoming) is for the supervisory agencies to announce that there is a strong presumption that when there is a bank failure, uninsured depositors would not be fully protected unless this is the cheapest way to resolve the failure. It is important to recognize that although large banking institutions may be too big to liquidate, they can be closed with losses imposed on uninsured creditors. Indeed this is exactly what FDICIA suggests should be done by specifying that, except under very unusual circumstances when the a bank failure poses "serious adverse effects on economic conditions or financial stability", a least-cost resolution procedure will be used to close down the bank. Ambiguity is created about the use of this systemic-risk exception to the least-cost-resolution rule because to invoke it requires a two-thirds majority of both the Board of Governors of the Federal Reserve System and the directors of the FDIC, as well as the approval of the secretary of the Treasury.

An important concern is that the systemic-risk exception to least-cost resolution will always be invoked when the failing bank is large enough because the Fed, the FDIC and the secretary of the Treasury will be afraid to impose costs on depositors and other creditors when a potential financial crisis is looming. Thus too-big-to-fail will still be alive, with all the negative consequences for moral-hazard risk-taking by the largest institutions. One way to cope with this problem is for the authorities to announce that although they are concerned about systemic risk possibilities, there will be a strong presumption that the first large bank to fail will not be treated as too-big-to-fail and costs will be imposed on uninsured depositors and creditors when the bank is closed. Rather than bail out the uninsured creditors at the initial large bank that fails, the authorities will stand ready to extend the safety net to the rest of the banking system if they perceive that there is a serious systemic risk problem.

The advantage of announcing such a stance is that it creates constructive ambiguity for the large banks because their uninsured depositors and creditors now have to worry that if this bank is the first one to fail, they will not be bailed out. (The phrase "constructive ambiguity" may have a somewhat negative connotation because it seems to imply advocacy of randomness in the supervision process. The constructive ambiguity advocated here is closer to a contingent rule, but one in which some judgement needs to be applied by supervisors.) As a result these depositors and 
creditors will now have an incentive to withdraw their funds if they worry about the soundness of the bank, even if it is very large, and this will alter the incentives of the bank away from taking on too much risk. Clearly, moral hazard still remains in the system because the authorities stand ready to extend the safety net to the rest of the system after the initial large institution fails if its failure creates the potential for a banking crisis. However, the extent of moral hazard is greatly reduced by the use of this form of constructive ambiguity. Furthermore, the cost of this remaining moral hazard must be balanced against the benefits of preventing a banking crisis if the initial bank failure is likely to snowball into a systemic crisis.

One potential criticism of a presumption towards allowing the first large bank to fail is that there is a substantial risk of contagion through the payments system. ${ }^{11}$ The payments system relies on substantial extensions of intraday, overnight and longer-term credit between banks. Failure of a large bank or one that is intimately involved in the large-dollar payments system could then lead to a systemic shock that could cause the payments system to freeze up or, at a minimum, lead to substantial losses at other banks. Thus attention needs to be paid to reduction of potential payment system and contagion problems.

Indeed, the FDICIA legislation of 1991 has done exactly this by taking important steps to deal with these problems through several provisions. FDICIA directed the Board of Governors of the Federal Reserve to develop a regulation which would limit interbank credit exposure, and the Board of Governors responded with Regulation F, which restricts the interday exposure to a not adequately capitalized correspondent to less than $25 \%$ of the bank's capital. To prevent a systemic liquidity problem from developing because other financial institutions might not have immediate access to their funds at a failed bank, FDICIA also authorizes the FDIC to make a final settlement

\footnotetext{
${ }^{11}$ Another potential criticism of a presumption that only the first large bank to fail will impose costs on uninsured depositors and creditors is that creditors have incentives to pump capital into a failing institution to prop it up just long enough so that it will not be the first one to fail. There are several reasons to discount this criticism. First is that the free-rider problem strongly mitigates the incentive for creditors to prop up the bank: each creditor individually is quite happy to let the other creditors pump funds into the bank in order to delay the failure, and so the incentive of creditors to prop up the bank is greatly weakened. Second, is that constructive ambiguity does not guarantee that delaying the failure of the bank will do any good. If the regulatory authorities decide that failure of a second bank does not present the financial system with systemic risk, they may not decide to protect the creditors. Thus the incentive for creditors to prop up the bank temporarily will be further weakened.
} 
with creditors when it assumes receivership of a failed bank. The settlement rate is based on the FDIC's average recovery experience. In addition, FDICIA explicitly recognizes contractual netting agreements and holds them legally binding, thereby reducing short-term credit exposure and making the clean up after a bank failure substantially easier.

Not only do these FDICIA provisions to limit interbank risk make it more likely that a large bank failure will not produce a systemic problem, but they also improve the incentives for the regulatory agencies to allow the first large bank to fail because the failure has less potential to do damage to the banking system. Thus, provisions of this type increase the credibility of the presumption that the first big bank will be allowed to fail and incur costs on the depositors and creditors, an essential feature of constructive ambiguity.

The constructive ambiguity procedures outlined here still leaves a good part of the government safety net in place which means that moral hazard incentives continue to exist for financial institutions to take on too much risk because of decreased incentives for depositors to discipline them. This is why constructive ambiguity must be combined with vigilant supervision, particularly of large financial institutions, in order to lessen the dangers presented by the technologically-driven changes in the financial system that we are seeing today.

\section{Conclusions}

The accelerating pace of technological progress is producing a financial system in which information and transactions costs have been falling dramatically. Improved information has opened up the securities markets as a source of funds to households and smaller businesses, with the result that the traditional financial intermediary business of acquiring funds and making private loans has been in decline. Financial intermediaries now function to unbundle risks, permitting more assets to be funded by less informed investors, thereby enhancing liquidity. Lower transactions costs have led to new means of delivering services electronically, which expands the scope of markets. Technology has thus been a driving force improving the efficiency of the financial system. 
Despite these benefits, technological progress presents policymakers with some important challenges. First, with markets becoming larger and more contestable, defining geographic and product markets narrowly becomes more problematic. With narrow definitions, antitrust policy to deal with the increasing size of financial institutions might stifle the growth of efficient firms and slow financial innovation. Second, financial consolidation and the trend towards new activities of financial intermediaries require the exploration of new methods to preserve the safety and soundness of the financial system. A combined system of vigilant supervision and constructive ambiguity to deal with failures of larger institutions along the lines we have suggested should be capable of mitigating the potential for increased risk-taking and help preserve the health of the financial system. 


\section{References}

Akerlof, George, 1970, “The Market for Lemons: Quality Uncertainty and the Market Mechanism," Quarterly Journal of Economics 89, 488-500.

Allen, Franklin and Anthony M. Santomero, 1997, "The Theory of Financial Intermediation," Journal of Banking and Finance 21 (11/12), 1461-85.

Berger, Allen N., Hunter, William C., and Timme, Stephen G., 1993, "The Efficiency of Financial Institutions: A Review and Preview of Research Past, Present and Future." Journal of Banking and Finance 17, 221-49.

Berger, Allen N., and Loretta J. Mester, 1997, "Inside the Black Box: What Explains Differences in the Efficiencies of Financial Institutions?" Journal of Banking and Finance 21, 895-947.

Berlin, Mitchell and Loretta J. Mester, 1997, "Why is the Banking Sector Shrinking? Core Deposits and Relationship Lending," mimeo, April 1997.

Bhasin, Vijay and Mark Carey, 1998, "The Determinants of Corporate Loan Liquidity," mimeo, September, 1998.

Berger, Allen N., Rebecca S. Demsetz and Philip E. Strahan, forthcoming, "The Consolidation of the Financial Services Industry: Causes, Consequences, and Implications for the Future," Journal of Banking and Finance.

Berger, Allen N., Timothy H. Hannan, 1989, The Price-Concentration Relationship in Banking, Review of Economics and Statistics 71, 291-99.

Berger, Allen N., William C. Hunter and Stephen G. Timme, 1993, "The Efficiency of Financial 
Institutions: A Review and Preview of Research Past, Present and Future," Journal of Banking and Finance 17.

Berger, Allen N., Loretta J. Mester, 1997, "Inside the Black Box: What Explains Differences in the Efficiencies of Financial Institutions?, Journal of Banking and Finance 21, 895-947.

Cyrnak, A., Hannan, Timothy H., 1998, "Bank Lending to Small Businesses and the Use of CRA Loan Data to Measure Market Structure,” Federal Reserve Board working paper.

Carey, Mark, Steven Prowse, John Rea and Gregory Udell, 1993, "The Economics of the Private Placement Market," Federal Reserve Board of Governors, Staff Study no. 166.

Edwards, Franklin R. and Frederic S. Mishkin, 1995, “The Decline of Traditional Banking: Implications for Financial Stability and Regulatory Policy, Federal Reserve Bank of New York Economic Policy Review 1(2), 27-45.

Economides, Nicholas R., Glenn Hubbard and Darius Palia, 1996, "The Political Economy of Branching Restrictions and Deposit Insurance: A Model of Monopolistic Competition among Small and Large Banks," Journal of Law and Economics 39.

Evanoff, Douglas and Fortier, Diana, 1988, "Reevaluation of the Structure-Conduct-Performance Paradigm in Banking," Journal of Financial Research 1, 277-294.

Hancock, Diana, David B. Humphrey and James A. Wilcox, forthcoming, "Telecommunication Versus Processing Cost and the Consolidation of the Payments System," Journal of Banking and Finance.

Hannan, Timothy H. and Allen N. Berger, 1991, "The Rigidity of Prices: Evidence from the Banking Industry, American Economic Review 81, 938-45. 
Hannan, Timothy H., 1997, "Market Share Inequality, the Number of Competitors, and the HHI: An Examination of Bank Pricing," Review of Industrial Organization 12, 23-35.

Hubbard, R. Glenn and Palia, Darius, 1995, ”Executive Pay and Performance: Evidence from the U.S. Banking Industry," Journal of Financial Economics 39, 105-30.

Jackson, William E. III, 1997, "Market Structure and the Speed of Price Adjustments: Evidence of Non-monotonicity, Review of Industrial Organization 12, 37-57.

Jayaratne, Jith, and Philip E. Strahan, 1998, "Entry Restrictions, Industry Evolution and Dynamic Efficiency: Evidence from Commercial Banking, Journal of Law and Economics 49, 23974.

Keeley, Michael, 1990, “Deposit Insurance, Risk and Market Power in Banking," American Economic Review 80, 1183-1200.

Kroszner, Randall S., Philip E. Strahan, 1997, “The Political Economy of Deregulation: Evidence from the Relaxation of Bank Branching Restrictions in the United States," Federal Reserve Bank of New York, research paper no. 9720.

Levonian, Mark, 1997, "Changes in Small Business Lending in the West," FRBSF Economic Letter no. 97-02.

Mester, Loretta J., 1997, "What's the Point of Credit Scoring?" Federal Reserve Bank of Philadelphia Business Review September/October, 3-16

Mishkin, Frederic S., 1998, "Financial Market Reform," paper presented at the conference, Economic Policy Reform: What We Know and What We Need to Know, at the Center for Research on Economic Development and Policy Reform, Stanford University, September 
17-19, 1998.

Mishkin, Frederic S., forthcoming, "Financial consolidation: Dangers and opportunities," Journal of Banking and Finance.

Moore, Robert R., and Thomas F. Siems, 1998, "Bank Mergers: Creating Value or Destroying Competition?" Federal Reserve Bank of Dallas, Financial Industry Issues, third quarter.

Neumark, David and Steven A. Sharpe, 1992, "Market Structure and the Nature of Price Rigidity: Evidence from the Market for Consumer deposits, Quarterly Journal of Economics 107, 657-80.

Oppenheim, Sara, 1996, “Would Credit Scoring Backfire in a Recession?” American Banker (November 18, 1996)

Radecki, Lawrence J., 1998, “The Expanding Geographic Reach of Retail Banking Markets,” Federal Reserve Bank of New York Economic Policy Review 4, 15-34.

Radecki, Lawrence J., John Wenninger, and Daniel K. Orlow, 1997, “Industry Structure: Electronic Delivery's Potential Effects on Retail Banking," Journal of Retail Banking Services 19(4), 57-63.

Rhoades, Steven A., 1996, “Bank Mergers and Industrywide Structure, 1980-94,” Board of Governors of the Federal Reserve System, staff study no. 169. 
Schranz, Mary, 1993, “Takeovers Improve Firm Performance: Evidence from the Banking Industry," Journal of Political Economy 101, 299-326.

Wolff, Edward N., 1998, "Recent Trends in the Size Distribution of Household Wealth,” Journal of Economic Perspectives 12(3), 131-50. 
Table 1

Depository Institutions Have Lost Market Share

\begin{tabular}{|c|c|c|c|}
\hline & \multicolumn{3}{|c|}{$\begin{array}{l}\text { Assets in billions of } 1998 \text { dollars } \\
\text { (Market share) }\end{array}$} \\
\hline & 1980 & 1990 & 1998 \\
\hline \multirow[t]{2}{*}{ Mutual Funds } & 277 & 1,398 & 4,635 \\
\hline & $(3.6)$ & $(10.5)$ & $(21.1)$ \\
\hline \multirow[t]{2}{*}{ Pension Funds } & 1,327 & 3,017 & 6,179 \\
\hline & $(17.3)$ & $(22.7)$ & $(28.2)$ \\
\hline \multirow[t]{2}{*}{ Finance Companies } & 403 & 722 & 839 \\
\hline & $(5.3)$ & $(5.4)$ & $(3.8)$ \\
\hline \multirow[t]{2}{*}{ Insurance } & 1,223 & 2,302 & 3,556 \\
\hline & $(16.0)$ & $(17.3)$ & $(16.2)$ \\
\hline \multirow[t]{2}{*}{ Commercial Banks } & 2,805 & 4,015 & 5,298 \\
\hline & $(36.6)$ & $(30.1)$ & $(24.2)$ \\
\hline \multirow[t]{2}{*}{ Other Depositories } & 1,628 & 1,865 & 1,414 \\
\hline & $(21.2)$ & $(14.0)$ & $(6.5)$ \\
\hline \multirow[t]{2}{*}{ All Depositories } & 4,433 & 5,880 & 6,712 \\
\hline & $(57.8)$ & $(44.1)$ & $(30.7)$ \\
\hline \multirow[t]{2}{*}{ Total } & 7,663 & 13,319 & 21,921 \\
\hline & $(100.0)$ & $(100.0)$ & $(100.0)$ \\
\hline
\end{tabular}

Source: Actual values are from the Flow of Funds, Table L. 109, L. 114, L.115, L.116, L. 117, L. 118, L. 119, L. 120, L. 121, L.122, L.123, L.127, L. 128. 


\section{Table 2}

\section{The Banking Industry Consolidates}

\begin{tabular}{|c|c|c|c|}
\hline \multirow[b]{2}{*}{ Assets } & \multicolumn{3}{|c|}{$\begin{array}{l}\text { Percent of gross domestic assets } \\
\text { (Number of banking companies) } \\
\text { [Number of banks] }\end{array}$} \\
\hline & 1990 & 1996 & 1998 \\
\hline Under $\$ 100$ & 7.8 & 5.5 & 4.7 \\
\hline \multirow[t]{2}{*}{ million } & $(6,817)$ & $(4,842)$ & $(4,521)$ \\
\hline & {$[7,041]$} & {$[5,023]$} & {$[4,682]$} \\
\hline$\$ 100$ million $-\$ 1$ & 14.8 & 14.0 & 13.2 \\
\hline \multirow[t]{2}{*}{ billion } & $(2,286)$ & $(2,325)$ & $(2,363)$ \\
\hline & {$[3,304]$} & {$[3,217]$} & {$[3,212]$} \\
\hline$\$ 1$ billion - $\$ 10$ & 18.5 & 13.6 & 13.8 \\
\hline \multirow[t]{2}{*}{ billion } & $(218)$ & (192) & $(210)$ \\
\hline & {$[1,180]$} & [737] & {$[801]$} \\
\hline$\$ 10$ billion - & 50.4 & 37.0 & 35.1 \\
\hline \multirow[t]{2}{*}{$\$ 100$ billion } & (67) & $(52)$ & $(48)$ \\
\hline & [817] & [492] & [333] \\
\hline Over $\$ 100$ & 8.5 & 29.9 & 33.2 \\
\hline \multirow[t]{2}{*}{ billion } & (3) & (9) & (10) \\
\hline & [28] & [106] & [71] \\
\hline \multirow[t]{3}{*}{ Total } & 100.0 & 100.0 & 100.0 \\
\hline & $(9,391)$ & $(7,420)$ & $(7,152)$ \\
\hline & {$[12,370]$} & {$[9,575]$} & {$[9,099]$} \\
\hline
\end{tabular}

Source: Call Reports. Size cutoffs are based on total assets (foreign plus domestic) in 1998 dollars. 

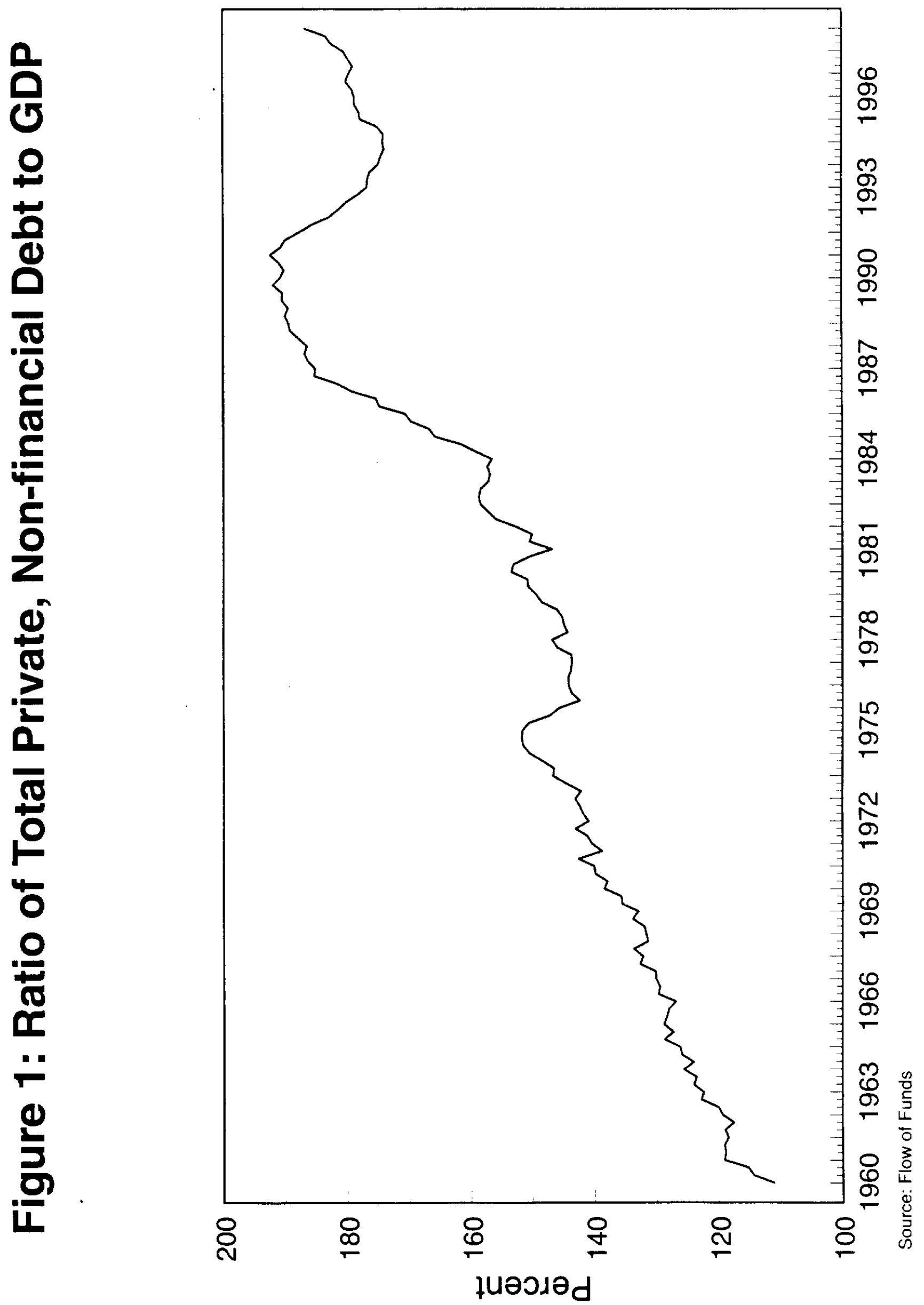

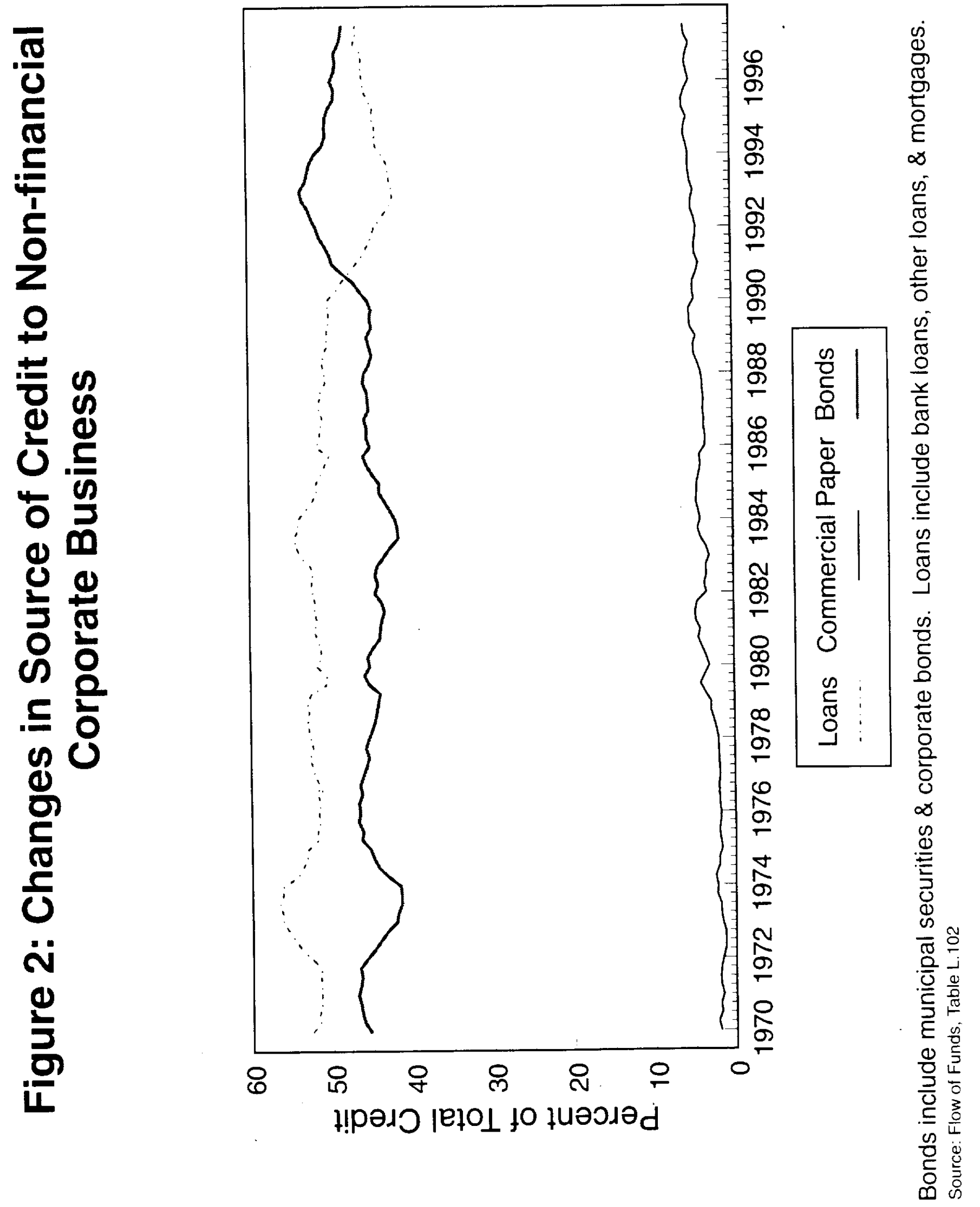


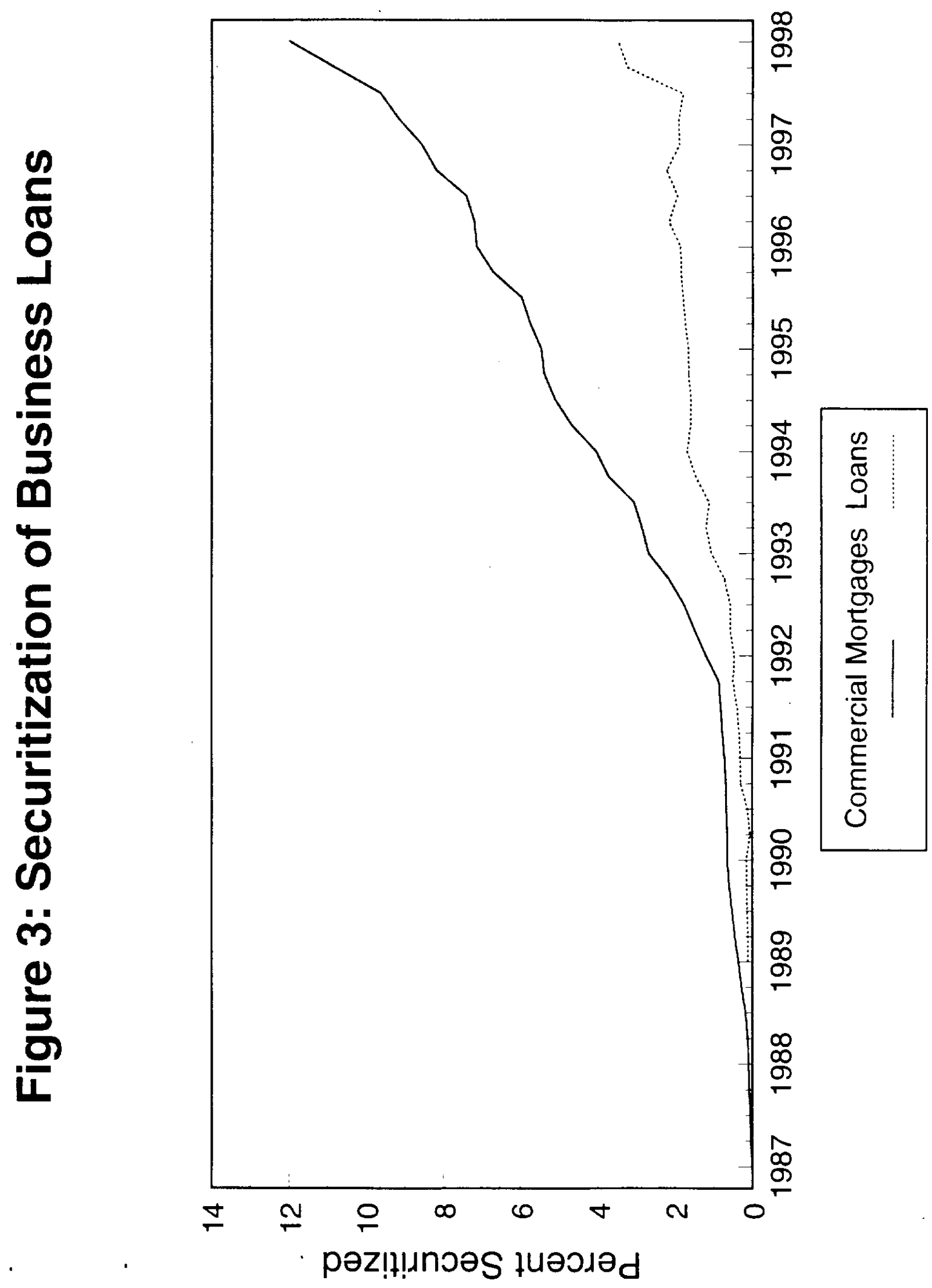




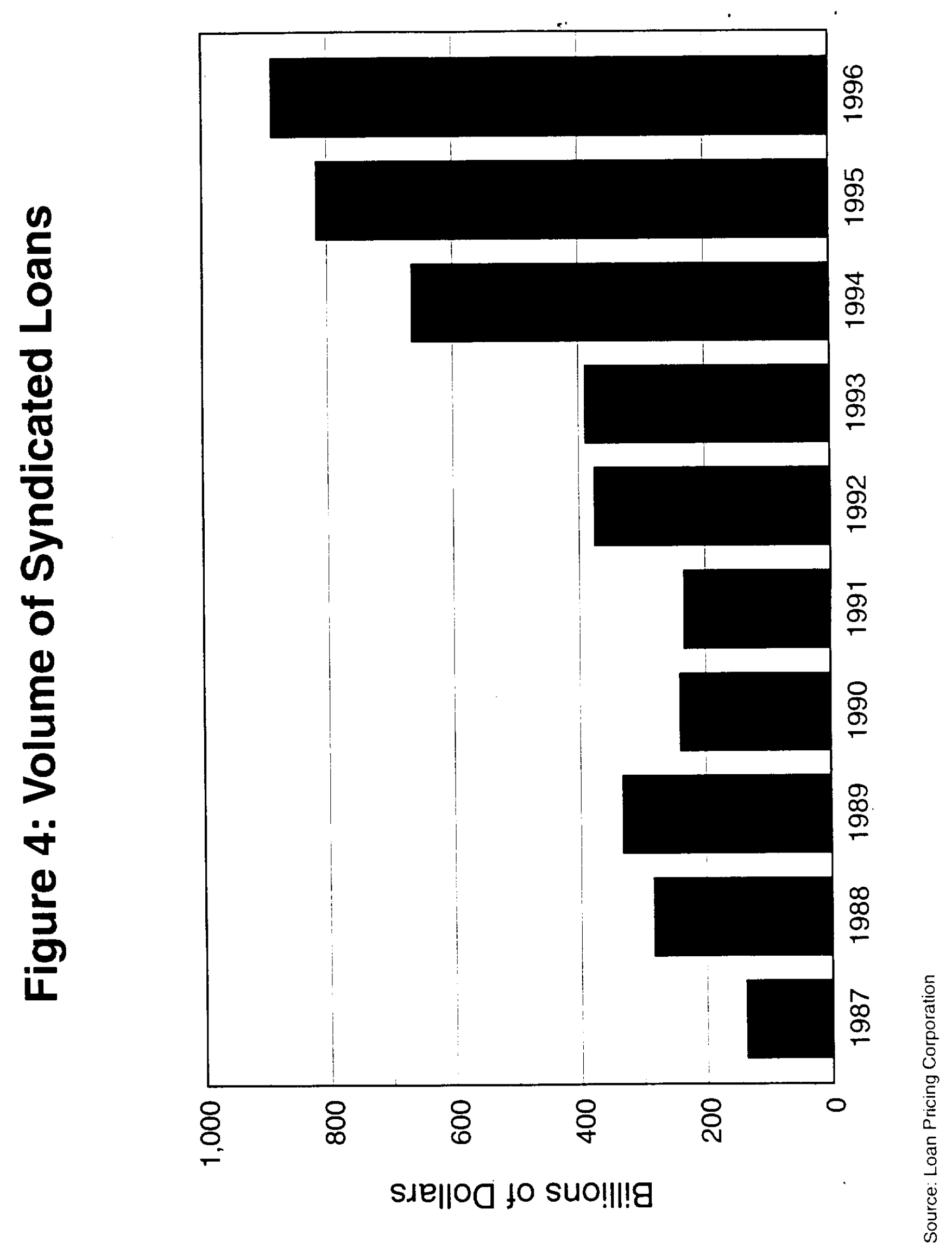




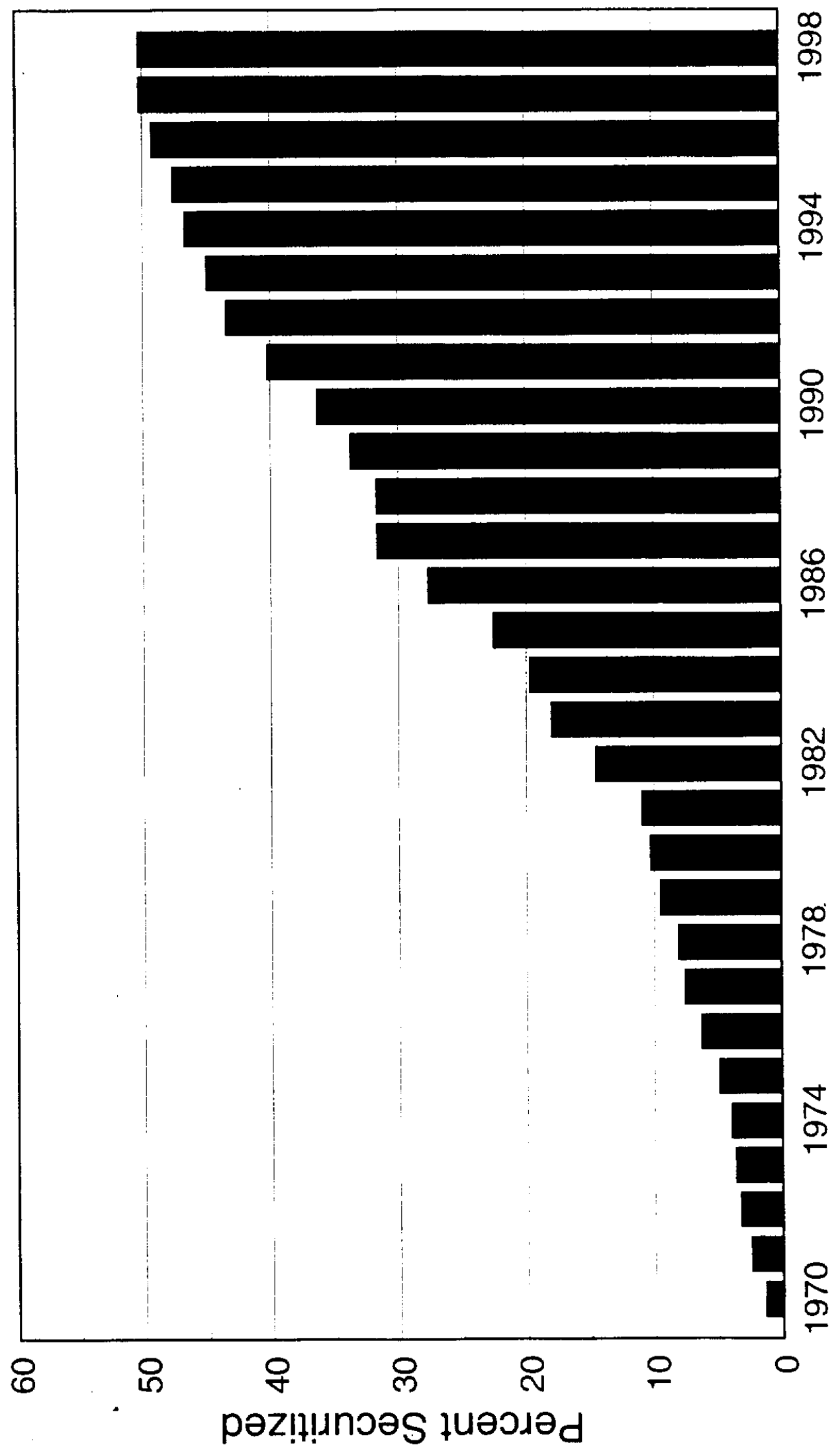



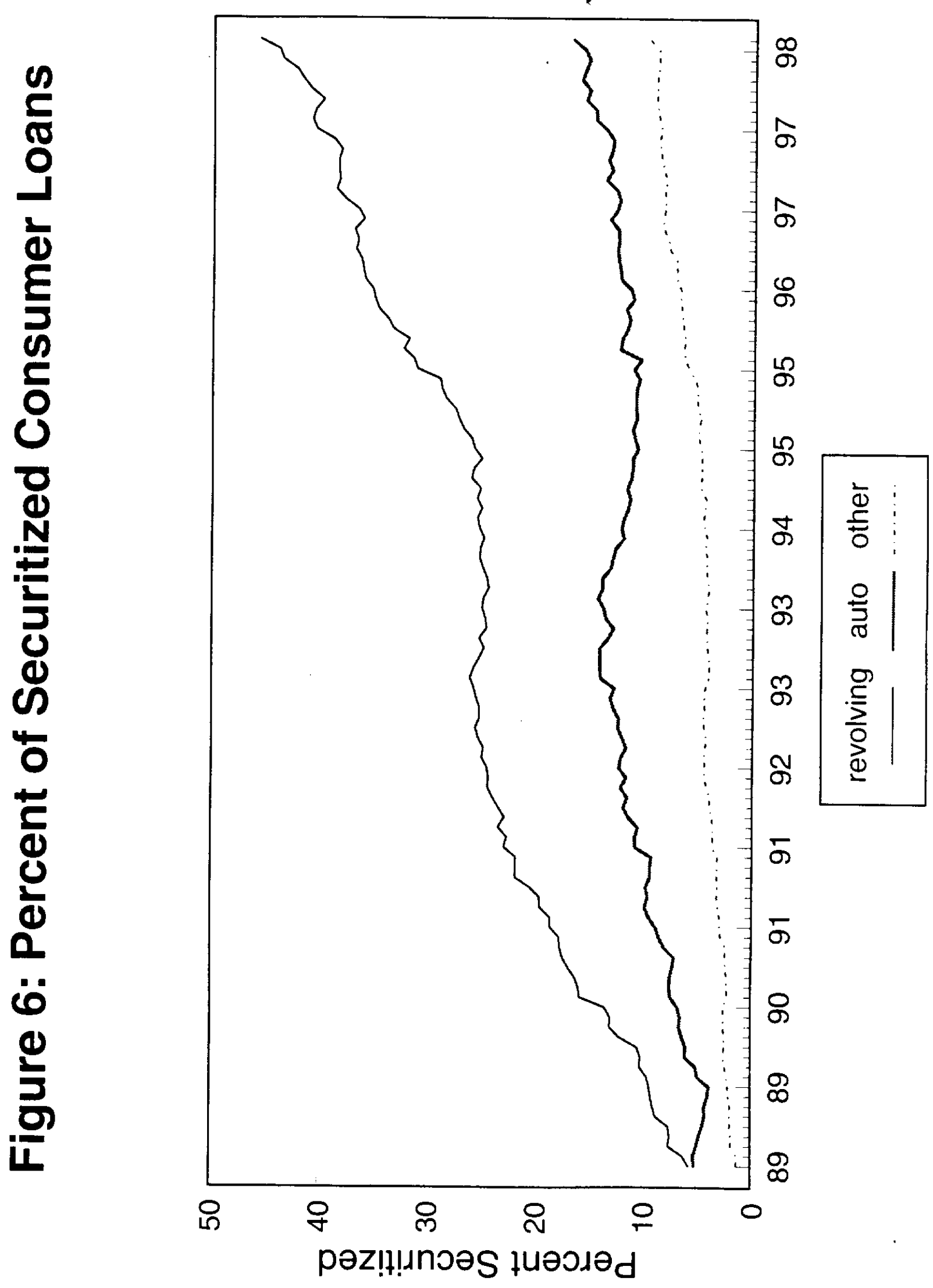


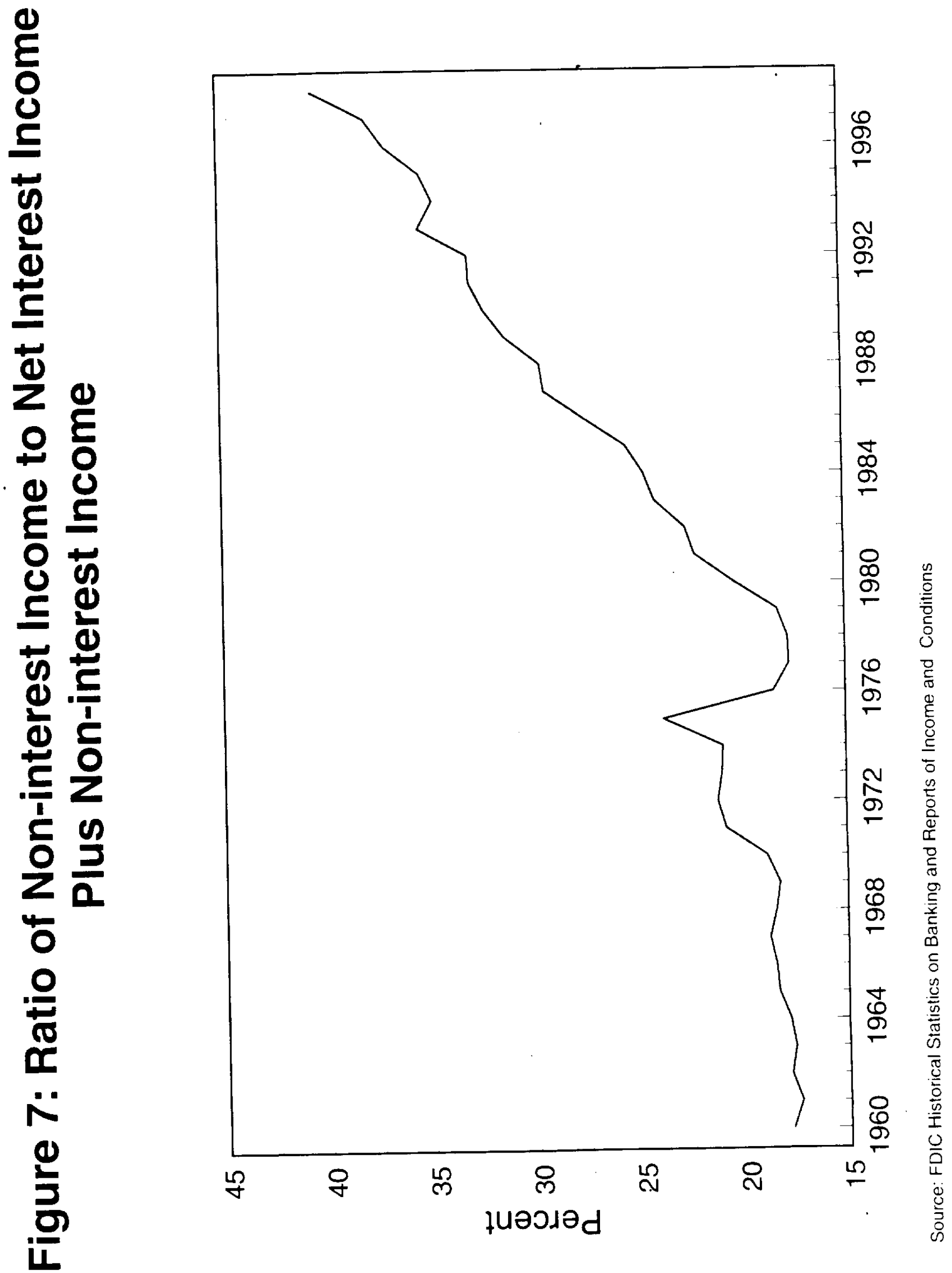

